\title{
Study of Potential Locations of Green Open Space Based on Procurement Convenience in West Jakarta
}

\author{
Prama Ardha Aryaguna ${ }^{1 *}$ (iD), Horas Maulite Andrey Gromiko², Kartika Pratiwi ${ }^{3}$ \\ ${ }^{1}$ Department Survey and Mapping, Faculty of Engineering, Universitas Esa Unggul, Jakarta, Indonesia \\ ${ }^{2}$ Dinas Cipta Karya Tata Ruang dan Pertanahan Pemerintahan Provinsi Jakarta, Indonesia \\ ${ }^{3}$ Faculty of Math and Science, Universitas Indonesia, Jakarta, Indonesia
}

\section{ARTICLE INFO}

Article History:

Received: August 20, 2021

Revision: November 18, 2021

Accepted: November 19, 2021

Keywords:

Green Open Space

GIS

Green Open Space Potential

Corresponding Author

E-mail:

prama.ardha@esaunggul.ac.id

\begin{abstract}
The Procurement of Public Green Open Space (RTH) in DKI Jakarta Province is carried out by the DKI Jakarta Forestry Service based on the land status of the BPN. The procurement of green open space is passive based on requests from the community. The DKI Jakarta Forestry Service data shows West Jakarta's public green open space has only fulfilled $8.8 \%$. This study aims to assist stakeholders in the procurement of green open space in terms of ease of procurement. The ease aspect is compiled from land-use parameters, BPN land status, spatial pattern zoning, SIPPT, RTH Assets, and raw rice fields. The analysis results show that many areas included in the green zoning in West Jakarta have turned the function of land into built-up land, making it difficult for the local government to acquire land. This research found alternative lands with existing non-built land use conditions and clear land status and potential spatial pattern zoning targeted as green open space land acquisition targets. The analysis results show that from 4071 plots of land, there are 784 plots of land that are very potential with 179 ha. For potential land, there are 3234 plots of land with an area of $301 \mathrm{Ha}$ and 53 plots of land classified as standard with an area of 2.4 Ha. Land with great potential can be used as a procurement priority for the relevant local government in the procurement of green open space in terms of the ease of procurement aspect.
\end{abstract}

\section{INTRODUCTION}

West Jakarta is part of the provincial capital, which has a function as the center of government and the economy to encourage the rapid development of built-up land in the form of residential and non-residential, which results in the conversion of green open space land to non-green (Karunia \& Ikhwali, 2021; Nagasawa et al., 2015; Pangaribowo, 2018; Putri, Ratih Fitria, et al., 2019). Based on Law no. 26 of 2007 concerning Spatial Planning, the plan for the provision and utilization of green open space is one of the contents in the city area's spatial planning, which consists of public green open space with a proportion of $20 \%$ of the city area.

The reduction in green areas is a threat because Jakarta, which is a metropolitan area, has an overload, lack of clean water, the danger of flooding, low air quality, and limited land (Edwinsyah \& Lutfi, 2021; Rifai et al., 2018; Samsuhadi, 2018; Study \& Sudirman, 2020). The limitations of green open space have environmental and social implications, such as the absence of places for early childhood and adolescents to play activities and increasingly limited space for social interaction (Enssle \& Kabisch, 2020; Rasidi et al., 2018). According to (Kruizse et al., 2019), the increase in a city's density often 
displaces or degrades green open spaces. Over time, the quality has decreased and the quantity (Setiowati et al., 2018). The existence of green open space has a significant influence on the air quality in a city. (Maulidia, 2018; Ramdhoni et al., 2016) The condition of green open space is directly proportional to the air quality.

The use of green open space is not only for improving air quality and the environment but can also be used as an evacuation room for natural disasters (Matos et al., 2019; Nath et al., 2018). According to (Rashifah et al., 2019), green open space can be used as an earthquake evacuation room with types of green open space such as rice fields, sports fields, and open areas. Green open space as part of the urban ecosystem plays a vital role in the environment, economy, and society (Mensah, 2014). For this reason, the DKI Jakarta Provincial Government needs a land acquisition strategy for green open space to meet the community's needs.

Table 1. Area of RTH assets in West Jakarta

\begin{tabular}{lrrrrrr}
\hline \multirow{2}{*}{ Districts } & \multicolumn{6}{c}{ RTH Typology / Area (Ha) } \\
\cline { 2 - 7 } & \multicolumn{1}{c}{$(\mathrm{H} 1)$} & \multicolumn{1}{c}{$(\mathrm{H} 2)$} & \multicolumn{1}{c}{$(\mathrm{H} 3)$} & \multicolumn{1}{c}{$(\mathrm{H} 4)$} & \multicolumn{1}{c}{ H7) } & \multicolumn{1}{c}{ Total } \\
\hline Cengkareng & 13,24 & 16,12 & 1,42 & 10,73 & 15,56 & 57,06 \\
Grogol Petamburan & 0 & 9,74 & 0 & 11,86 & 0,14 & 21,73 \\
Kalideres & 0 & 14,98 & 74,16 & 3,34 & 1,76 & 94,24 \\
Kebon Jeruk & 0 & 6,24 & 5,34 & 5,17 & 1,09 & 17,84 \\
Kembangan & 16,08 & 14,63 & 10,61 & 10,09 & 7,83 & 59,25 \\
Palmerah & 0 & 6,64 & 2,18 & 5,82 & 0,04 & 14,69 \\
Tamansari & 0 & 2,43 & 0 & 2,65 & 2,4 & 7,49 \\
Tambora & 0 & 0,84 & 0 & 3,73 & 0,59 & 5,15 \\
\hline \multicolumn{1}{c}{$\quad$ Total } & 29,31 & 71,64 & 93,71 & 53,39 & 29,4 & 277,45 \\
\hline
\end{tabular}

Source: DKI Jakarta Forestry Service, 2020.

There have been many studies that have examined the suitability of land or land that has the potential to be used as green open space (Abebe \& Megento, 2017; Babalola, 2018; Tahmasebi et al., 2014; Widyawati et al., 2020); these publications only provide potential physical land without considering the legality and ease of land acquisition. In this study, an approach related to these matters was adopted so that the results of land that can be used as green open space become more specific and detailed.

\section{RESEARCH METHODS \\ Research Location}

The research location is in the National Capital, especially in West Jakarta. West Jakarta Administrative City is one of 6 regencies/cities in the DKI Jakarta Province. Geographically, West Jakarta is located between 5019'12" - 6023'54" South
Latitude dan 106'22'42" - 106 ${ }^{\circ} 58^{\prime} 18^{\prime \prime}$ East Longitude.

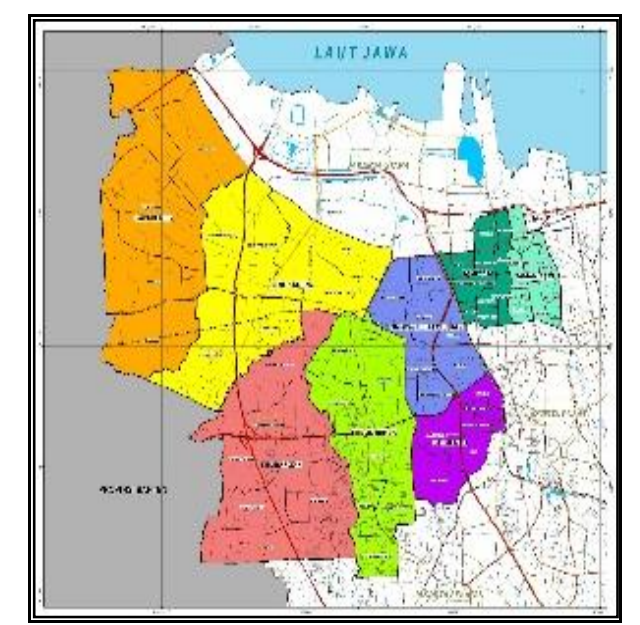

Figure 1. Location of the research area.

West Jakarta has an area of $125.43 \mathrm{~km} 2$ divided into eight sub-districts, 56 urban villages, and 586 RW. The current condition of RTH assets covering an area of 277.45 ha only fulfills $11.03 \%$ of the need for green open space. 


\section{RTH Parameters Based on Ease Potential Land Use}

Land use is an essential factor in determining green open space at a location. Land use will affect the level of convenience and the budgeting factor for the procurement of green open space. Sites that have built-up land use will have a higher cost and a higher level of difficulty related to purchasing land because it has been utilized. Therefore, the determined land is divided into three (3) classes: very potential, potential, and standard.

Table 2. Classification of potential land use

\begin{tabular}{cc}
\hline No & Information \\
\hline 1 & Other Green \\
2 & Horticulture \\
3 & Pool \\
4 & Empty land \\
5 & Sports field \\
6 & Nursery \\
7 & Swamp \\
8 & Ricefield \\
9 & Moor/Field \\
10 & Plants and Flowers \\
11 &
\end{tabular}

Source: Analysis results, 2021.

\section{RDTR Space Pattern}

The spatial pattern plan strongly influences the development of green open space in the RDTR. Its designation is divided into protection and cultivation functions. Land in the green zoning will be easier to buy because it is in accordance with the green space designation because land in the green zoning pattern will not be able to get out of the IMB. For non-green land, it can be used as green open space but with several challenges such as more expensive land prices, people's willingness to buy their land, land legality.

The blue open space zoning is the last priority because it has its own priority in procuring blue open space, which is useful for absorption, reservoir, and water control. The following is the classification of spatial patterns in terms of the priority of convenience in the procurement of green open space.

Table 3. Zoning classification of spatial

\begin{tabular}{lll}
\multicolumn{3}{c}{ patterns } \\
\hline No & Information & Criteria \\
\hline 1 & Green Zoning & Very \\
& & Potential \\
2 & Non-Green Zoning & Potential \\
3 & Blue Open Zoning & Normal \\
\hline
\end{tabular}

Source: Analysis results, 2021.

\section{SIPPT dan RTH Assets}

Analyzing SIPPT (Land Use Designation Permit) and Asset RTH is essential. The land that can be used as green open space is not land that has become an asset so that it does not cause conflict to the procurement process. RTH purchases and SIPPT used to belong to the local government and have not added asset data from the central government. In addition, based on research (Pantalone, 2010; Ustaoglu \& Aydinoglu, 2020), the area that is farthest from the existing park needs green open space because the site does not have green open space or vegetation so that the further away from RTH Assets, the more potential it will have.

\section{Rice Fields}

Even though West Jakarta is a metropolitan urban area, there are still locations that become Baku Sawah landbased on 2019 ATR/BPN data. The scope of raw rice fields in West Jakarta is $414 \mathrm{Ha}$. The land may not be converted because it has been stipulated in the regulations. This parameter is a factor that will be used to eliminate potential grounds based on the previous parameter analysis.

\section{Status of BPN's Land Parcels}

The status of BPN land parcels is an essential factor in determining the potential for green open space. The forestry service uses this parameter to determine whether the land will be purchased or not for land acquisition. The land used for land acquisition is the land status of SHM, HGB, and HP. Grounds that do not have land 
status or problematic status will be eliminated because it will be difficult to acquire land later.

\section{Potential RTH Based on Ease}

The modeling of potential green open space is composed of 5 main parameters, namely: land use, the spatial pattern of
RDTR, the status of land parcels, SIPPT, and green available space assets and raw rice fields. The modeling results will be classified into 3 (three) classes: very potential, potential, and regular. The following is an image of the research flow chart in determining the Potential Green Plan.

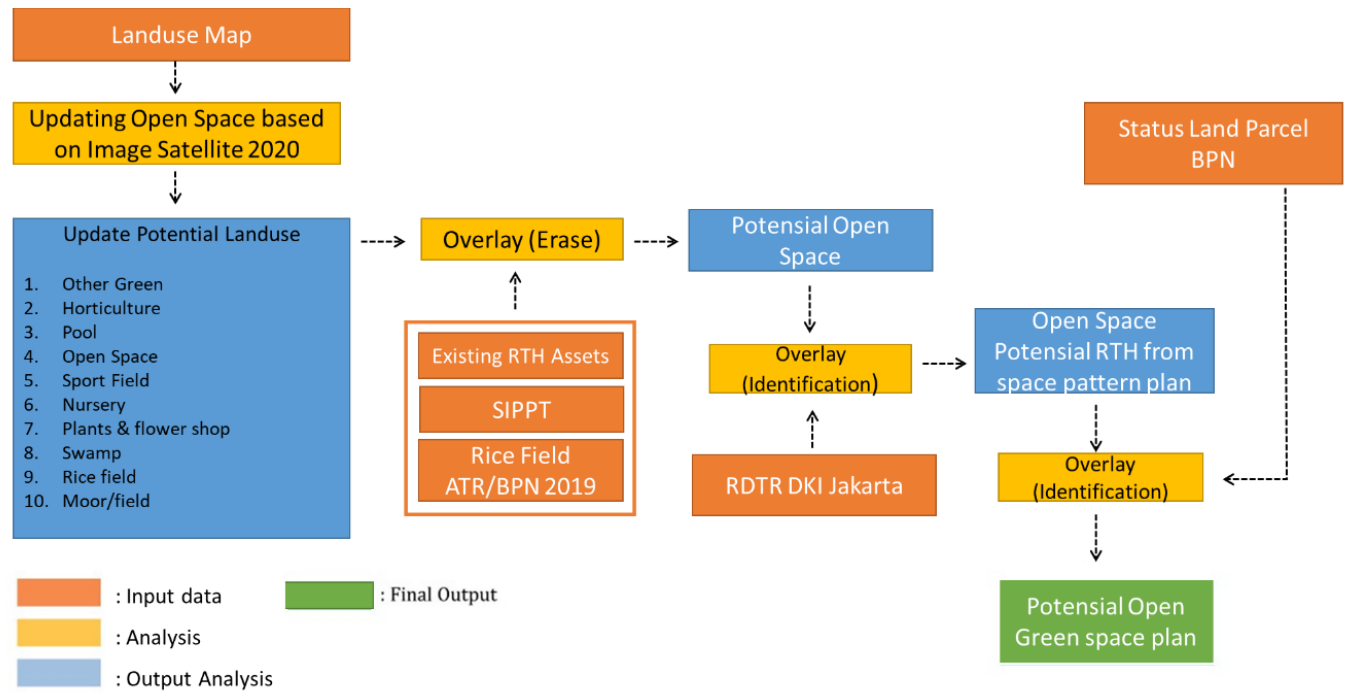

Figure 2. Flowchart of determining the potential green plan (Source: Analysis results, 2021)

\section{RESULTS AND DISCUSSION}

Potential Land Use Analysis

Based on the processing results, 11 land use classes have the potential to be used as green open space with the following areas.

Table 4. Potential land use area

\begin{tabular}{|c|c|c|}
\hline No & Classification & Area (Ha) \\
\hline 1 & Other Green & 446,62 \\
\hline 2 & Horticulture & 160,19 \\
\hline 3 & Pool & 111,49 \\
\hline 4 & Empty land & 614,96 \\
\hline 5 & Sports field & 1,79 \\
\hline 6 & Nursery & 3,14 \\
\hline 7 & Plants and Flowers shop & 1,94 \\
\hline 8 & Swamp & 1,37 \\
\hline 9 & Ricefield & 0,251 \\
\hline 10 & Moor/Field & 111,61 \\
\hline
\end{tabular}

Source: Analysis results, 2021.

The potential land use in West Jakarta is $14.06 \mathrm{~km}^{2}$ or $11.2 \%$ of the total area of West Jakarta. It can be seen that almost $90 \%$ of the land in West Jakarta is built-up land, so it is essential to use green open space optimally to improve the quality of the environment and the quality of life of its people. The following is a map of the distribution of potential land use in West Jakarta. 

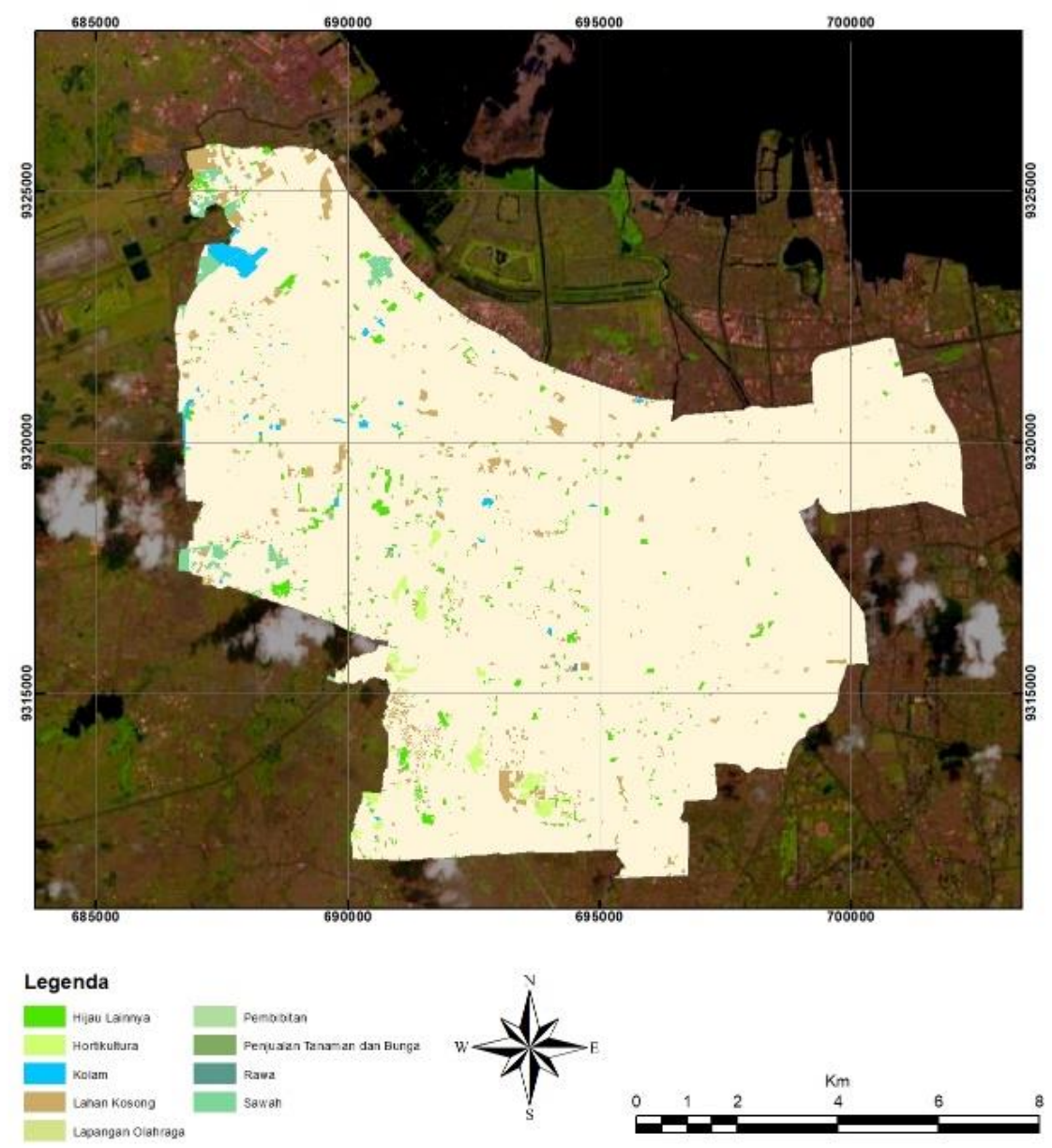

Figure 3. Distribution of Potential Land Use (Source: DKI DCKTRP, 2021).

The results of the distribution show that the area that has the most significant potential for the procurement of green open space in terms of land use is in Kalideres District

\section{Spatial Pattern Analysis}

Based on the spatial pattern analysis, there are four main classes related to zoning: Green Zoning, Non-Green Zoning, Blue Open Space Zoning, and Road Plans.

Table 5. Zoning grouping of RDTR ruang spatial patterns

\begin{tabular}{ccc}
\hline Green Zoning & Non-Green Zoning & $\begin{array}{c}\text { Blue Open Space } \\
\text { Zoning }\end{array}$ \\
\hline & National government zones; local \\
government; representatives of foreign & \\
countries; village housing; medium- & \\
high KDB housing; vertical & \\
zone; city/environmental & $\begin{array}{c}\text { housing; low KDB housing; low KDB } \\
\text { parks; burial; green }\end{array}$ & vertical housing; offices, trade, and \\
line; recreational green; & services; offices, trade, and standard & \\
& KDB services; mixture; public and & \\
& social services; industry and & \\
& warehousing; and & \\
& &
\end{tabular}

Source: DCKTRP, 2021. 
For green zoning land that has been utilized as a built-up land, it has exceeded $80 \%$, and only $\pm 20 \%$ remains. This is, of course, significantly worrying apart from a policy from the local government that will not carry out evictions. Still, conditions like this will undoubtedly decrease the quantity of green zoning if it is not immediately followed up to be utilized according to its utilization.
Based on the spatial pattern plan prepared by the DKI Provincial Government, it can be seen that the Kalideres sub-district is plotted to become an environmental buffer zone with the greenest zoning compared to other subdistricts.

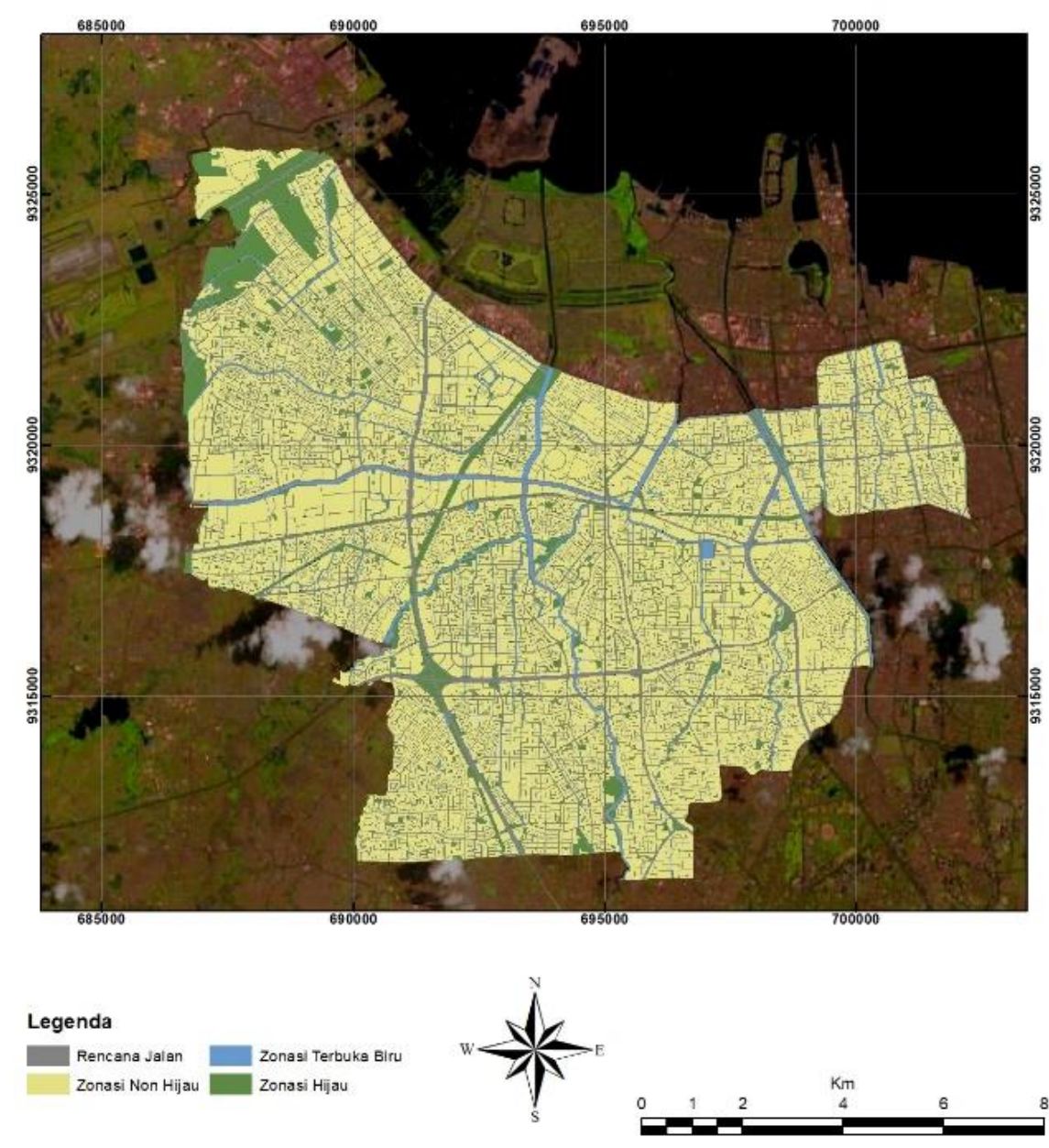

Figure 4. Zoning of Spatial Patterns (ource: DKI DCKTRP, 2021).

The condition of the Air Quality Index issued by IQAIR on April 23, 2021, shows that the average AQI value of West Jakarta ranges from 125 - 165, which, based on the classification, is included in the unhealthy class for sensitivity to unhealthy groups. The grouping of green zoning in the Banten border area will be challenging to improve and improve air quality in the central part of West Jakarta as it approaches the center so that there is a need for even distribution in the provision of green open space.

\section{Analysis of RTH and SIPPT Assets}

The RTH and SIPPT assets analysis is intended so that the potential land obtained does not overlap with the RTH and SIPPT assets owned by local governments. The inventory and data analysis results of green open space assets received from the forestry service were 277.5 ha, while for SIPPT, it was 5213, 5 ha. 


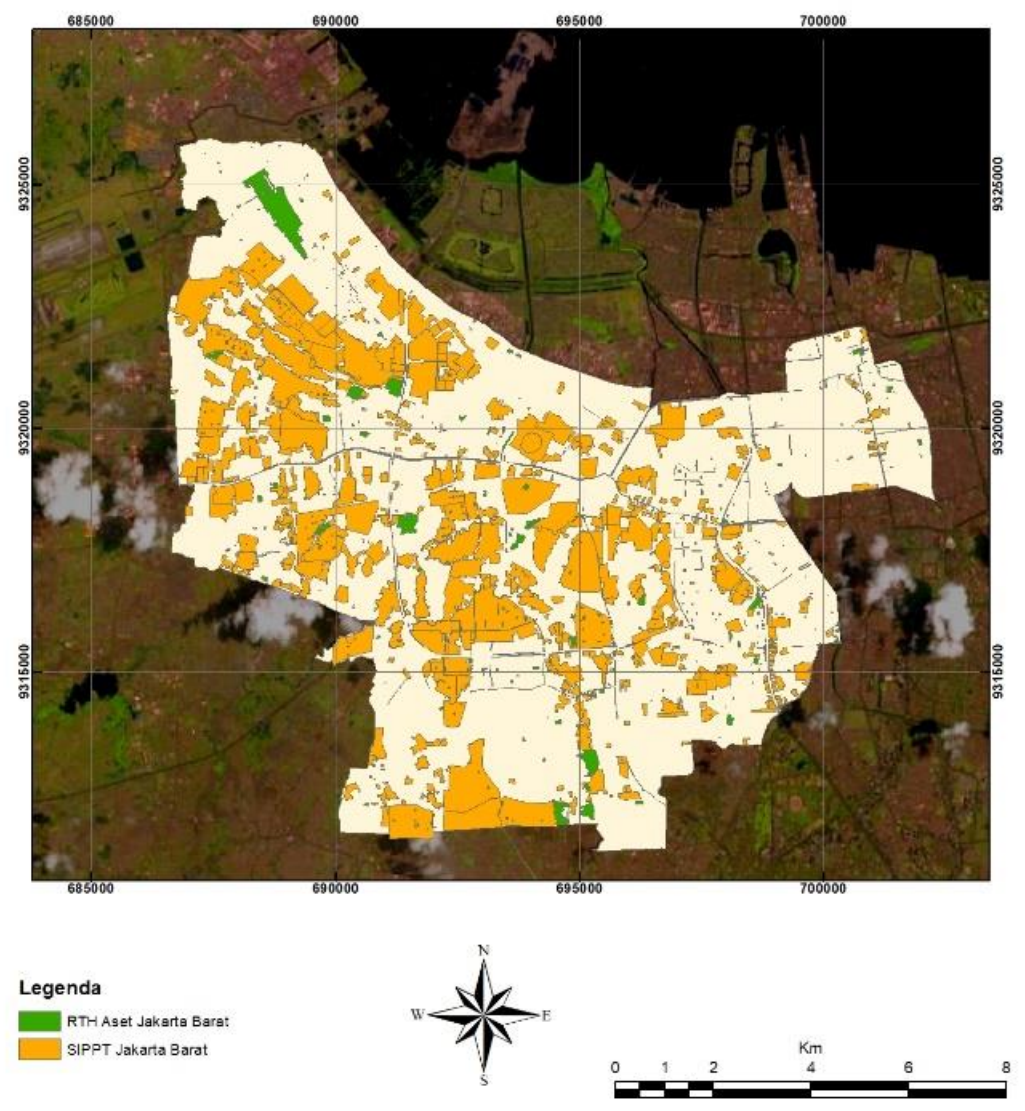

Figure 5. RTH Distribution and SIPPT assets (Source: Analysis results, 2021).

\section{Status of land parcels}

The status of land rights is an essential part of DKI Jakarta's provincial government in land acquisition for green open spaces. Purchase of land for land status whose validity has not been verified can lead to conflicts and risks in the future. In this case, land parcel data from the National Land Agency (BPN) is the reference used in this activity to make land purchases that can be accounted for and minimize conflicts.

The results of a review of BPN's 2019 parcel data in the West Jakarta area identified 319,689 parcels of land. Furthermore, if viewed from the availability of properties to the total area of West Jakarta, it is known that there are 38.48 hectares or $30.48 \%$ of the West Jakarta area that does not have data on land parcels.

Table 6. Areas without BPN parcels

\begin{tabular}{|c|c|c|c|c|}
\hline No & Districts & $\begin{array}{c}\text { Area District } \\
\left(\mathrm{km}^{2}\right)\end{array}$ & $\begin{array}{l}\text { Area Without Pesil } \\
\left(\mathrm{km}^{2}\right)\end{array}$ & $\begin{array}{l}\text { Percentage to } \\
\text { Region }\end{array}$ \\
\hline 1. & Tambora & 5.41 & 2.27 & 41.96 \\
\hline 2. & Kembangan & 24.97 & 8.30 & 33.24 \\
\hline 3. & Kalideres & 29.03 & 8.10 & 27.90 \\
\hline 4. & Cengkareng & 25.66 & 7.70 & 30.01 \\
\hline 5. & Grogol Petamburan & 10.83 & 2.98 & 27.52 \\
\hline 6. & Kebon Jeruk & 17.65 & 6.07 & 34.39 \\
\hline 7. & Taman Sari & 4.50 & 1.02 & 22.67 \\
\hline 8. & Palmerah & 7.37 & 2.04 & 27.68 \\
\hline & Total & 125.42 & 38.48 & 30.48 \\
\hline
\end{tabular}

Source: Analysis results, 2021. 
For the area of parcels with land ownership rights, namely $243.47 \mathrm{Ha}$, for 216.8 Ha and Use Rights with an area of 21.8 Building Use Rights covering an area of Ha

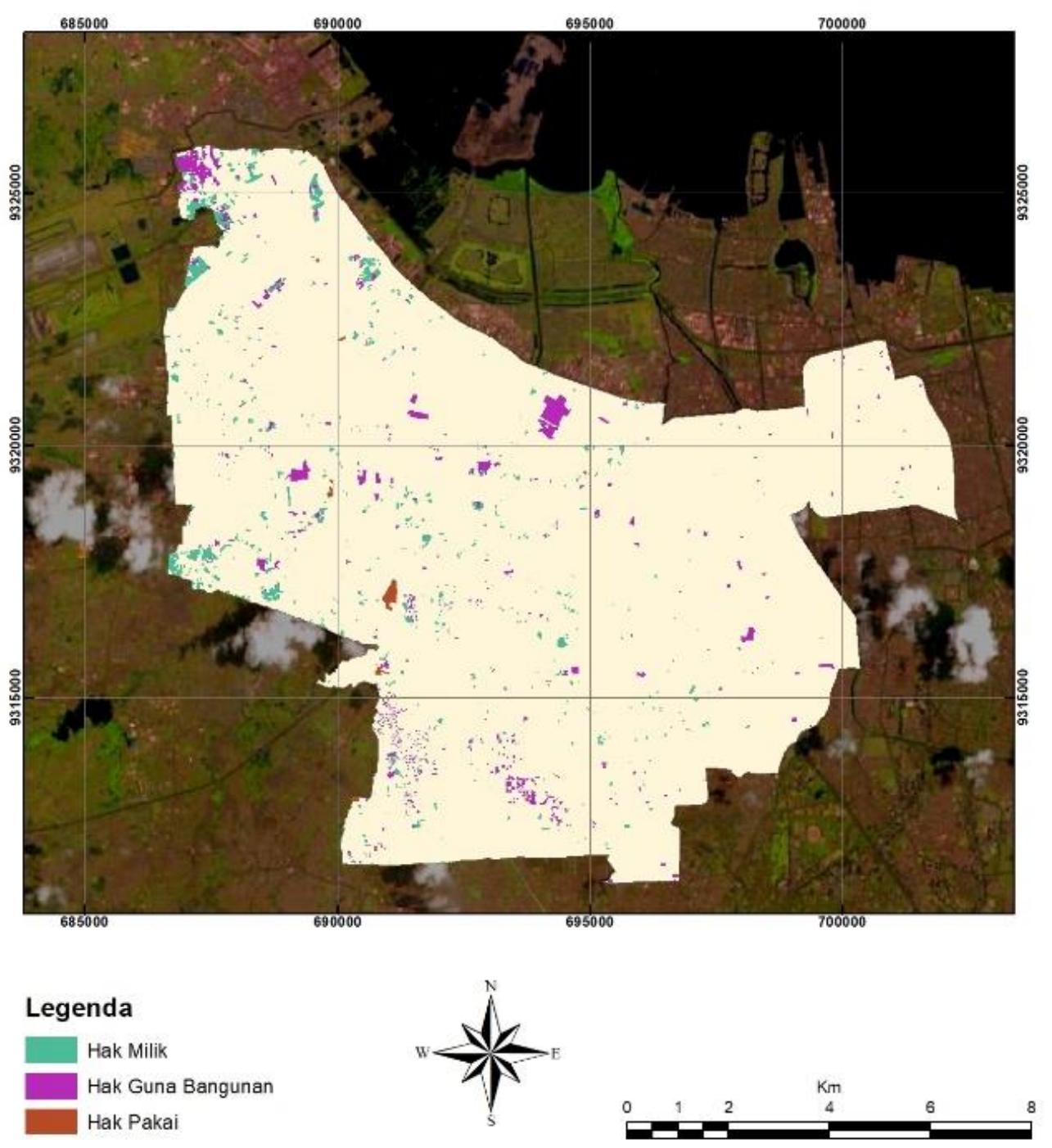

Figure 6. Status Parcel Distribution at West Jakarta (Source: Analysis results, 2021)

\section{Potential Green Space Based on Convenience}

The results of the overlay analysis of the six parameters resulted in a potential green space with a total of 4070 parcels with an area of 467.38 ha. Based on the research from convenience, the very potential land has a percentage of $19.26 \%$, for the possible class, it is $79.45 \%$, and the rest is in the ordinary course of $1 \%$. The potential land in the standard type is quite large but is experiencing shrinkage due to the unavailability of land parcels so that only $1 \%$ is left.
When viewed from the distribution of locations with a very potential class in terms of convenience, they are located in the Kalideres sub-district. The possible land situated on the border of West Jakarta with Tangerang Banten is a solution for local governments to increase the quantity of public green open space in West Jakarta. An increase in the amount of green open space will be more optimal if it is located in locations that need it not only grouped at one location so that the need for green open space can be met evenly. 


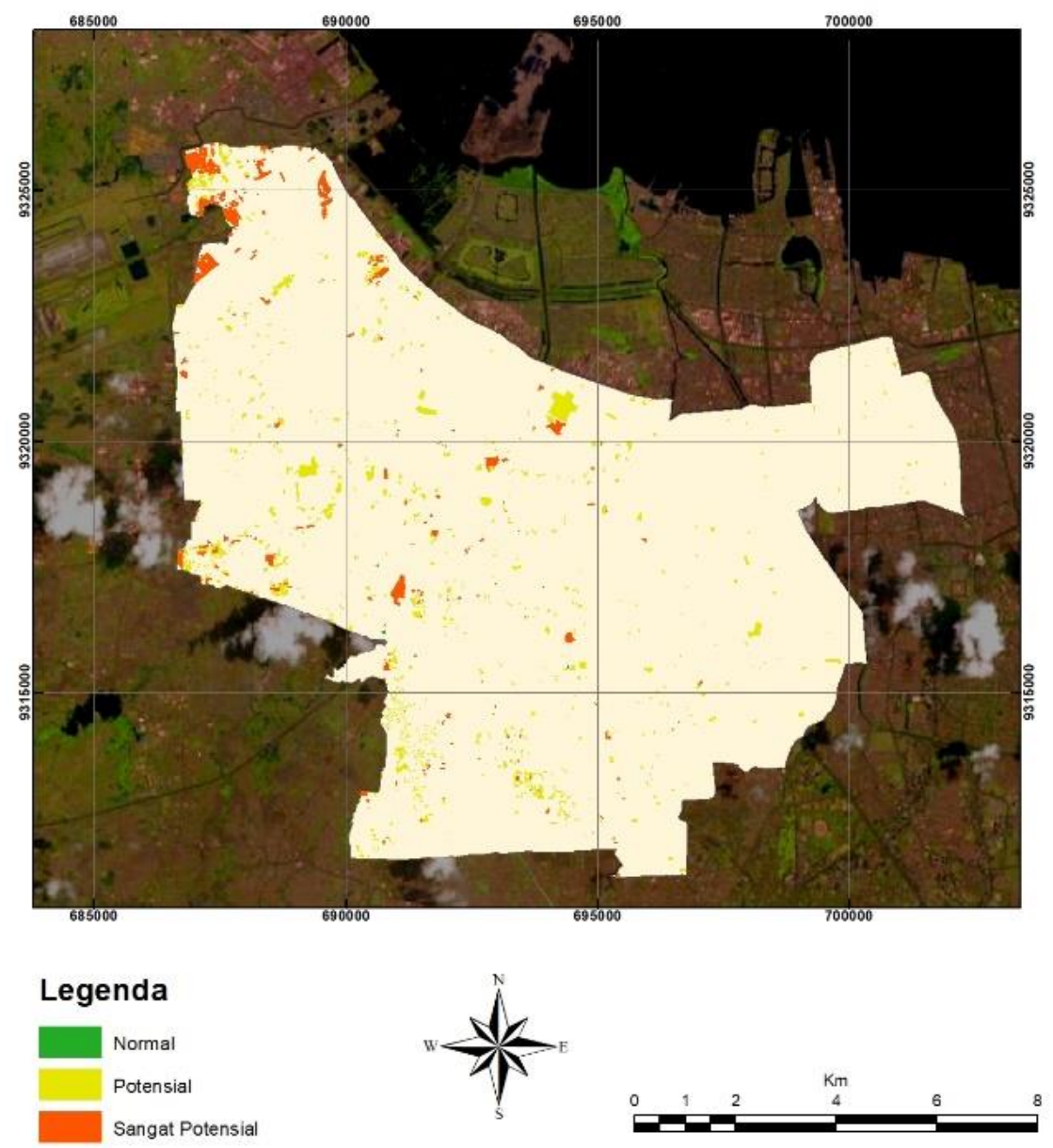

Figure 7. Potential Green Open Space Distribution (Source: Analysis results, 2021).

\section{CONCLUSION}

Based on the spatial analysis based on geographic information systems, it can be concluded that the modeling of potential green open space land based on convenience can be generated. This analysis looks at the potential of green open space based on land use data, spatial patterns, RTH Assets, SIPPT, raw rice fields, and BPN land parcels. Based on the analysis results, it was found that the number of potential packages was 4070 plots with an area of 467.38 hectares. Through this modeling, it is hoped that it can assist local governments in determining the land to be procured or purchased to increase the quantity of green open space in West Jakarta to improve the quality of the environment and the quality of life of the community.

\section{ACKNOWLEDGE}

Acknowledgments to Esa Unggul University for providing material and nonmaterial assistance, the department of copyright, land, and spatial planning of DKI Jakarta for data assistance for this research.

\section{REFERENCES LIST}

Abebe, M. T., \& Megento, T. L. (2017). Urban green space development using GIS-based multi-criteria analysis in Addis Ababa metropolis. December 2018. https://doi.org/10.1007/s12518-0170198-7

Babalola, M. A. (2018). Application of GISbased multi-criteria decision technique in exploration of suitable site options for anaerobic digestion of food and biodegradable waste in Oita City, Japan. Environments - MDPI, 5(7), 1-16. https://doi.org/10.3390/environmen ts5070077 
Edwinsyah, P., \& Lutfi, A. (2021). Strategi Pemerintah Provinsi Dki Jakarta Dalam Rangka Pengendalian Ruang Terbuka Hijau Melalui Pbb-P2. Syntax Literate: Jurnal Ilmiah Indonesia, 6(2), 524.

https://doi.org/http://dx.doi.org/1 0.36418 / syntax-literate.v6i2.2195

Enssle, F., \& Kabisch, N. (2020). Urban green spaces for the social interaction, health, and well-being of older people- An integrated view of urban ecosystem services and socio-environmental justice. Environmental Science \& Policy, 109, $36-44$. https://doi.org/https://doi.org/10.1 016/j.envsci.2020.04.008

Karunia, T. U., \& Ikhwali, M. F. (2021). Effects of population and land-use change on water balance in $\{D K I\}$ Jakarta. 622, 12045. https://doi.org/10.1088/17551315/622/1/012045

Kruizse, H., van der Vliet, N., Staatsen, B., Bell, R., Chiabai, A., Muiños, G., Higgins, S., Quiroga, S., MartinezJuarez, P., Yngwe, M. A., Tsichlas, F., Karnaki, P., Lima, M. L., de Jalón, S. G., Khan, M., Morris, G., \& Stegeman, I. (2019). Urban green space: creating a triple win for environmental sustainability, health, and health equity through behavior change. International Journal of Environmental Research and Public Health, 16(22). https://doi.org/10.3390/ijerph162244 03

Matos, P., Vieira, J., Rocha, B., Branquinho, C., \& Pinho, P. (2019). Modeling the provision of air-quality regulation ecosystem service provided by urban green spaces using lichens as ecological indicators. Science of The Total Environment, 665, 521-530. https://doi.org/https://doi.org/10.1 016/j.scitotenv.2019.02.023

Maulidia, G. (2018). Hubungan Keberadaan Ruang Terbuka Hijau dengan Kualitas Udara di Kota Semarang. Ruang, 4(1), 11-20.

https://doi.org/10.14710/ruang.4.1.1 $1-20$
Mensah, C. A. (2014). Urban Green Spaces in Africa: Nature and Challenges. International Journal of Ecosystem, 2014(1), 1-11. https://doi.org/10.5923/j.ije.2014040 1.01

Nagasawa, R., Fukushima, A., Yayusman, L. F., \& Novresiandi, D. A. (2015). Urban Expansion and Its Influences on The Suburban Land Use Change in Jakarta Metropolitan Region JABODETABEK ). Urban Planning and Design Research, 3(Figure 1), 7-16. https://doi.org/10.14355/updr.2015. 03.002

Nath, T. K., Zhe Han, S. S., \& Lechner, A. M. (2018). Urban green space and wellbeing in Kuala Lumpur, Malaysia. Urban Forestry \& Urban Greening, 36, 34-41.

https://doi.org/https://doi.org/10.1 016/j.ufug.2018.09.013

Pangaribowo, R. L. (2018). Dynamics of landuse change in urban area in West Jakarta. 106, 12040.

https://doi.org/10.1088/1755-

1315/106/1/012040

Pantalone, S. (2010). Creating the urban Forest: suitability analysis for green space in the City of Boston. Tuft University.

Putri, Ratih Fitria, Wibirama, Sunu, Giyarsih, Sri Rum, Pradana, Aditya, \& Kusmiati, Yanti. (2019). Landuse change monitoring and population density analysis of Penjaringan, Cengkareng, and Cakung Urban Area in Jakarta Province. E3S Web Conf., 76, 3004.

https://doi.org/10.1051/e3sconf/201 97603004

Ramdhoni, S., Rushayati, S. B., \& Prasetyo, L. B. (2016). Open Green, Space Development Priority, Based on Distribution of air Temperature Change in Capital City of Indonesia, Jakarta. Procedia Environmental Sciences, 33, 204-213. https://doi.org/https://doi.org/10.1 016/j.proenv.2016.03.071

Rashifah, N., Lanya, I., \& Utami, N. W. F. (2019). Identifikasi dan model ruang 
terbuka hijau sebagai ruang evakuasi bencana alam gempa bumi berbasis SIG di kawasan Sanur, Denpasar, Bali. Jurnal Arsitektur Lansekap, 5(1), 67. https://doi.org/10.24843/jal.2019.v05 i01.p08

Rasidi, M. H., Jamirsah, N., \& Said, I. (2018). Development of Urban Green Space Affects Neighbourhood Community Social Interaction. Asian Journal of Environment-Behaviour Studies, 3(8), 79-88. https://doi.org/10.21834/ajebs.v3i8.281

Rifai, A., Rusfiana, Y., Gunawan, R., Studi, P., \& Pertahanan, S. (2018). Kerjasama Kodim 0503/JB dengan Pemkot Jakarta Barat ... | Rifai, Rusfiana, Gunawan | 29. Jurnal Strategi Dan Kampanye Militer, 4(3), 29-50. http://139.255.245.7/index.php/SMK /article/view / 275

Samsuhadi, S. (2018). Pemanfaatan Air Tanah Jakarta. Jurnal Air Indonesia, 5(1).

https://doi.org/10.29122/jai.v5i1.242 8

Setiowati, R., Hasibuan, H. S., \& Koestoer, R. H. (2018). Green open space masterplan at Jakarta Capital City, Indonesia for climate change mitigation. IOP Conference Series: Earth and Environmental Science, 200(1), 0-8. https://doi.org/10.1088/17551315/200/1/012042

Study, A. C., \& Sudirman, J. (2020). Pola Pemanfaatan Ruang Terbuka Hijau Pada Area Sempadan Bangunan: Studi Kasus Kawasan Jalan Jenderal Sudirman Jakarta The Use Of Green Open Space In Building Setback Area. Arsitekta: Jurnal Arsitektur Dan Kota Berkelanjutan, 2(1), 43-53. sempadan bangunan, ruang terbuka, pusat bisnis

Tahmasebi, E., Jalali, M., Gharehghashlo, M., \& Nicknamfar, M. (2014). Urban park site selection at local scale by using geographic information system (GIS) and analytic hierarchy process ( $A H P$ ). 4(3), 357-365.

Undang-Undang Republik Indonesia Nomor 26 Tahun 2007 Penataan Ruang
26 April 2007. Lembaran Negara Republik Indonesia Tahun 2007 Nomor 4725. Jakarta.

Ustaoglu, E., \& Aydınoglu, A. C. (2020). Site suitability analysis for green space development of Pendik district (Turkey). Urban Forestry $\mathcal{E}$ Urban Greening, 47, 126542. https://doi.org/https://doi.org/10.1 016/j.ufug.2019.126542

Widyawati, L. F., Aryaguna, P. A., \& First, A. Y. (2020). Land Procurement for Green Open Spaces in South Jakarta Using GIS-based Multiple Criteria Analysis. Lifeways: International Journal of Society, Development and Environment in the Developing World, 4(1), 35-47. 